\title{
From Subsistence to Commercial Rice Production in Laos
}

\section{Vongpaphane Manivong and Rob Cramb}

\section{INTRODUCTION}

The rice sector in Laos is in a "sticky situation" in several senses. First, Laos is considered the centre of origin of glutinous or sticky rice (Muto et al. 2016) and this type of rice still accounts for around $90 \%$ of production (Schiller et al. 2006; Mullen et al. 2019). Second, of the four countries considered in this volume, Laos has suffered the most from variability in rice production due to the high incidence of droughts and floods (Schiller et al. 2001, 2006). Third, this variability has made it difficult to achieve a reliable rice surplus at the national level, hindering investment in the processing capacity needed to develop a viable export industry. Fourth, the continued strong preference for growing glutinous varieties for domestic consumption has limited export growth to niche markets within the region where glutinous rice is consumed. Finally, the pursuit of market

\footnotetext{
V. Manivong $(\bowtie)$

Ministry of Agriculture and Forestry, Vientiane, Laos

R. Cramb

School of Agriculture and Food Sciences, University of Queensland, St Lucia, QLD, Australia

e-mail: r.cramb@uq.edu.au

(C) The Author(s) 2020

R. Cramb (ed.), White Gold: The Commercialisation of Rice

Farming in the Lower Mekong Basin, https://doi.org/10.1007/978-981-15-0998-8_5
} 
liberalisation within a socialist political regime has created a certain "stickiness" in policymaking institutions-a feature shared with Vietnam (Nguyen et al. 2017). All of this means that rice farming in Laos is the least commercialised within the Lower Mekong.

Nevertheless, as in the region as a whole, there has been a remarkable transformation of rice-based farming systems and supply chains over recent decades, including both the intensification of rice production in favourable lowland areas and the diversification of rural livelihoods to combine rice with non-rice and non-farm activities (Manivong et al. 2014; Cramb and Newby 2015). These changes reflect the broad process of agricultural commercialisation as outlined in Chap. 1. In this chapter we outline the context and trends for rice farming in Laos as a whole. Subsequent chapters present case studies of commercialisation in Savannakhet and Champasak Provinces, focusing on a comparison of rainfed and irrigated systems (Chap. 6), the supply of the key inputs of seed and fertiliser (Chap. 7 ), the domestic and cross-border marketing of surplus paddy and rice (Chap. 8), and the economic constraints to further intensification in the main wet-season rice crop (Chap. 9).

\section{The Context of Rice Farming in Laos}

Laos occupies an area of $236,800 \mathrm{~km}^{2}$, stretching $1700 \mathrm{~km}$ from north to south and between 140 and $500 \mathrm{~km}$ from east to west (MINC 2000; Fig. 5.1). Officially, three administrative regions are recognised: the Northern, Central, and Southern Regions. The Northern Region comprises seven provinces, the Central Region seven provinces (including the Vientiane Capital), and the Southern Region four provinces. The country shares a border of $416 \mathrm{~km}$ with China in the north, $236 \mathrm{~km}$ with Myanmar in the northwest, $1370 \mathrm{~km}$ with Thailand in the west, $492 \mathrm{~km}$ with Cambodia in the south, and $1957 \mathrm{~km}$ with Vietnam in the east (MAF 2010). Eighty-five per cent of the country's surface area lies within the Lower Mekong Basin, with only the rivers of Xam Neua Province in the north-east flowing east into Vietnam. The Mekong forms the western border of Laos for most of its length, except for Xaignbouli Province in the north-west, which lies to the west of the river and Champasak Province in the south, which the river bisects before entering Cambodia.

The majority of land in Laos is classified as mountainous, covering approximately $80 \%$ of the total land area; over two-thirds of the land has slopes of greater than $30 \%$ (MAF 2010). The landscape can be divided 


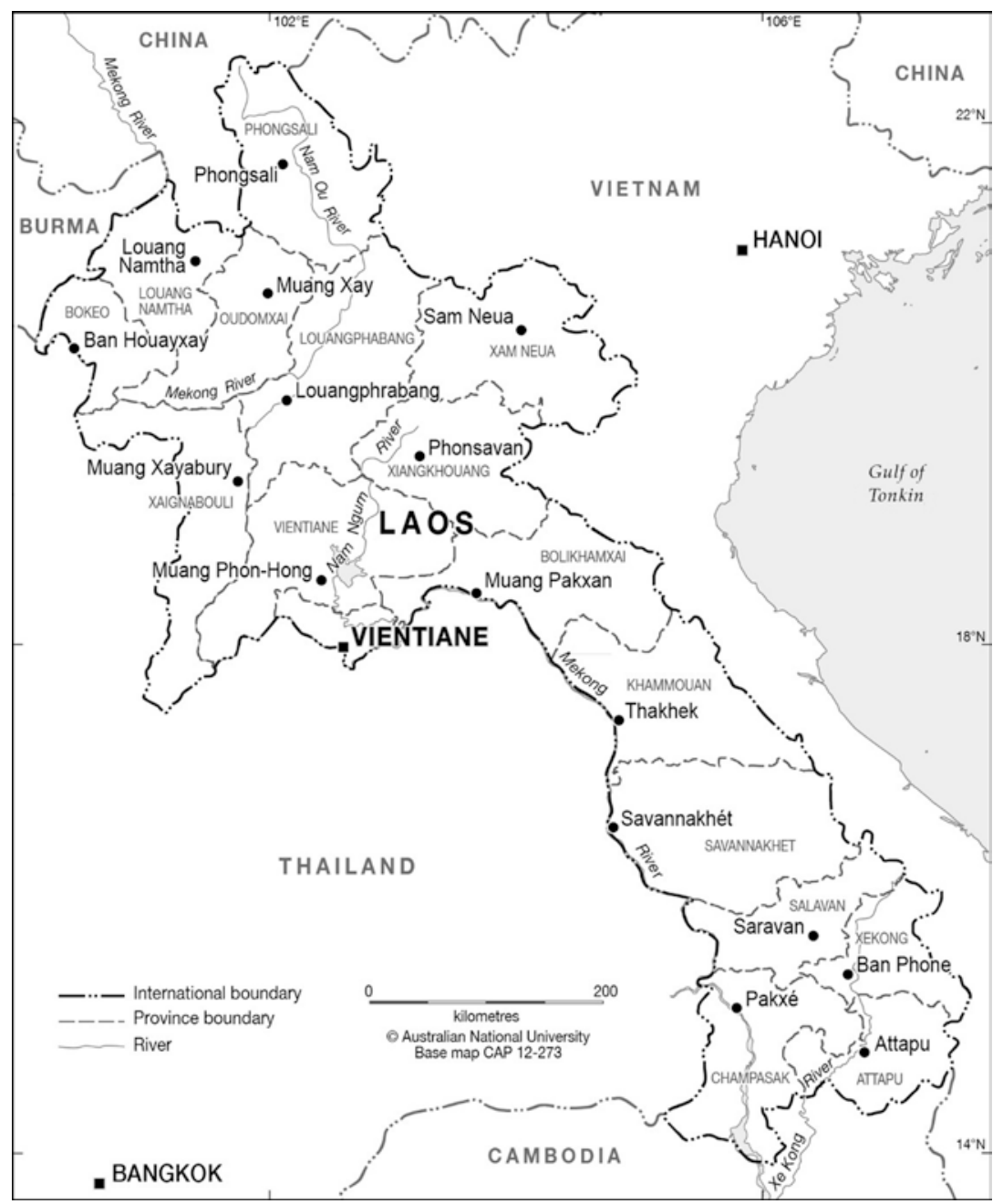

Fig. 5.1 Laos with provinces and provincial capitals, 2012. (Source: CartoGIS Services, College of Asia and the Pacific, The Australian National University)

into the mountainous north, the eastern mountain chain, and the plains (MINC 2000). The mountainous north is dominated by rugged mountains with an average elevation of $1500 \mathrm{~m}$ above sea level. The eastern mountain chain (the Annamite Range) stretches along the border with Vietnam. Three large plateaus are located in this region, namely, the 
Phuan Plateau in Xiengkhuang Province, the Nakai Plateau in Khammuan Province, and the Bolaven Plateau in the southern provinces. The plains include fourteen minor plains, twelve of which are in located in intermontane basins in the Northern Region, and seven major plains, all located along the Mekong Valley, from the Vientiane Plain in the Central Region to the Champasak Plain in the Southern Region. The majority of lowland rainfed and irrigated rice-growing areas in the country are located in these major plains, the three most important of which are the Vientiane, Savannakhet, and Champasak Plains.

Laos has a tropical savannah climate dominated by the monsoons, with about $90 \%$ of the annual rainfall falling in the wet season from May to October while some months during the dry season between November and April may have no rainfall (see Fig. 1.2 in Chap. 1). The mean annual precipitation is $1600 \mathrm{~mm}$, but this varies significantly among regions, ranging from $1000 \mathrm{~mm}$ in much of the Northern Region to over $3500 \mathrm{~mm}$ in the Bolaven Plateau in the Southern Region. It is estimated that about 270,000 million $\mathrm{m}^{3}$ of the annual rainfall in Laos runs off into the Mekong River and contributes around 35\% of the river's total annual flow (ICEM 2003). Although the climate in Laos is mostly tropical, it phases into subtropical in the mountainous areas in the north and along the mountain chain bordering Vietnam in the east. The temperature averages $25{ }^{\circ} \mathrm{C}$ throughout the country and the day and night temperatures differ by 10 ${ }^{\circ} \mathrm{C}$. The daily temperature increases to as high as $37{ }^{\circ} \mathrm{C}$ in Champasak Province in the wet season, but drops to as low as $8{ }^{\circ} \mathrm{C}$ in Huaphan Province in the dry season (NSC 2005).

The population of Laos was estimated to be 7.1 million in mid-2019, with an annual growth rate of $1.5 \%$. With a total area of $236,800 \mathrm{~km}^{2}$, Laos has the lowest population density in Asia-around 31 persons per $\mathrm{km}^{2}$ - though this varies widely from 10 persons per $\mathrm{km}^{2}$ in mountainous Phongsaly Province in the extreme north to over 200 persons per $\mathrm{km}^{2}$ in Vientiane Capital (MPI and UNDP 2009). About half the population has settled in the large plains along the Mekong Valley (NSC 2004). The population of Laos is ethnically diverse. The 2005 Population and Housing Census reported that nearly $55 \%$ of the total population is of the Lao ethnic group, $11 \%$ is of the Khmu ethnic group, and $8 \%$ is of the Hmong ethnic group. Most of the lowland rice farmers belong to the Lao and other Tai groups such as the Phouthai.

After decades of civil war, the Lao People's Democratic Republic (PDR), a single-party socialist republic, was declared in 1975. Two year 
later, the Lao Government developed the first development plan for 1978-1980 with the main focus on the development of agriculture as the fundamental base for economic development of the country. Agriculture was promoted in the form of collective production or cooperatives by increasing farm areas and supporting the use of farm machinery and irrigation facilities in order to raise production and achieve self-sufficiency in rice. The number of cooperatives rose rapidly to total 3976 nationwide by 1986 (Evans 1988). However, as reported by several authors (Evans 1995; Stuart-Fox 1997), by the early 1990s most of the listed cooperatives existed in name only and in reality very few cooperatives were actually working. The unsuccessful implementation of collective production was due to top-down management, low efficiency, shortage of inputs, lack of trained staff, and farmers' reluctance to follow the strict working conditions imposed (Stuart-Fox 1996).

In 1986 the New Economic Mechanism (NEM) was introduced to transform the country from a centrally planned economy to a marketoriented economy. The principles of the NEM were to free prices based on market demand and supply and encourage private investment from both domestic and foreign investors. ${ }^{1}$ The government also improved infrastructure, in particular transport and communication facilities, to support the transformation to a market economy and integration with regional and international markets (UNDP 2002). Since the adoption of the NEM there has been considerable social and economic development. GDP growth averaged $6 \%$ during the 1990 s, $7 \%$ during the 2000 s, and $8 \%$ during the 2010s (World Bank 2019). Thus GDP per capita increased from USD 324 in 2000 to USD 2457 in 2017 and the incidence of poverty has been reduced from 39\% in 1997 to $23 \%$ in 2012 (World Bank 2019).

\section{Rice-Based Farming Systems}

Farming systems in Laos can be broadly classified based on their occurrence in lowland, upland, and plateau environments (Table 5.1). In the lowlands, rainfed and irrigated farming systems are practised. In the sloping uplands, people have relied heavily on shifting cultivation. In the plateau environment, cash crops and fruit trees are extensively grown, replacing shifting cultivation. Noticeably, apart from the cultivation of the staple food (rice), a variety of home-garden vegetables and different types of livestock appear in almost all farming categories to serve daily house- 
Table 5.1 Main farming systems in Laos

\begin{tabular}{|c|c|c|}
\hline Environment & $\begin{array}{l}\text { Farming } \\
\text { system }\end{array}$ & Characteristics \\
\hline \multirow[t]{2}{*}{ Lowlands } & $\begin{array}{l}\text { Lowland } \\
\text { rainfed } \\
\text { farming } \\
\text { system }\end{array}$ & $\begin{array}{l}\text { Single cropping of traditional glutinous rice varieties. Buffaloes } \\
\text { and cattle for draught, cash income, and occasional meat, free } \\
\text { ranging during the dry season, confined in the wet season. } \\
\text { Pigs, poultry, fish, and non-timber forest products (NTFPs) } \\
\text { important for food and cash income. }\end{array}$ \\
\hline & $\begin{array}{l}\text { Lowland } \\
\text { irrigated } \\
\text { farming } \\
\text { system }\end{array}$ & $\begin{array}{l}\text { Double cropping of traditional photoperiod-sensitive rice } \\
\text { varieties, with higher use of improved varieties, fertiliser, and } \\
\text { other inputs for the second crop which is mainly for cash. } \\
\text { Dry-season vegetables grown near urban centres. Relatively few } \\
\text { livestock due to shortage of grazing land, buffaloes used for } \\
\text { ploughing, small stock for meat and cash income. }\end{array}$ \\
\hline \multirow[t]{2}{*}{ Uplands } & $\begin{array}{l}\text { Upland } \\
\text { rainfed } \\
\text { farming } \\
\text { system }\end{array}$ & $\begin{array}{l}\text { Shifting cultivation of rice intercropped with a variety of cash } \\
\text { crops on sloping land. Fruit tree species also grown in lower } \\
\text { altitudes. Pigs, cattle, and poultry are the principal livestock. } \\
\text { High dependence on NTFPs for income to purchase rice, etc. } \\
\text { Adoption of paddy cultivation is progressing where possible in } \\
\text { small inland valleys. }\end{array}$ \\
\hline & $\begin{array}{l}\text { Highland } \\
\text { farming } \\
\text { system }\end{array}$ & $\begin{array}{l}\text { Similar to upland rainfed farming system, but with high- } \\
\text { altitude crops such as maize and (formerly) opium, sometimes } \\
\text { intercropped with lettuce and mustard, and temperate fruit } \\
\text { trees such as plum, peach, and local apple. }\end{array}$ \\
\hline Plateaus & $\begin{array}{l}\text { Plateau } \\
\text { farming } \\
\text { system }\end{array}$ & $\begin{array}{l}\text { Coffee, tea, and cardamom have largely replaced shifting } \\
\text { cultivation, supplemented by fruit trees and vegetables in home } \\
\text { gardens. Cattle important as savings and enterprise, pigs and } \\
\text { poultry also kept. }\end{array}$ \\
\hline
\end{tabular}

Source: Adapted from UNDP (2002: 76)

hold consumption needs and play a key role in household saving and income generation.

Rice production is the main farming activity in Laos, accounting for over $80 \%$ of the total cultivated area (Bestari et al. 2006). Rice is grown in three main farming systems, namely, the rainfed lowland, irrigated lowland, and rainfed upland systems (Table 5.2). Rice cultivation in the rainfed lowlands normally commences at the beginning of the wet season in May or June, depending on the arrival of the rains, with land preparation involving two passes of ploughing and one harrowing (Table 5.3). Rice seed is sown in a nursery and one month later the young seedlings are transplanted to the main field. The harvesting period is in October or 
Table 5.2 Three major rice-based farming systems

\begin{tabular}{ll}
\hline Farming system & Characteristics \\
\hline Rainfed lowland & $\begin{array}{l}\text { Rice is grown in wet season in bunded fields flooded for at least part } \\
\text { of the season; water from rainfall }\end{array}$ \\
Irrigated lowland & $\begin{array}{l}\text { Rice is grown in wet and dry seasons in bunded fields flooded for at } \\
\text { least part of the season; water from irrigation and rainfall } \\
\text { Rice is grown in wet season in unbunded fields on sloping land under } \\
\text { shifting cultivation system; water from rainfall }\end{array}$ \\
\hline Rainfed upland
\end{tabular}

Source: Adapted from Linquist et al. (2006: 29)

Table 5.3 Seasonal rice cropping calendar for different farming systems

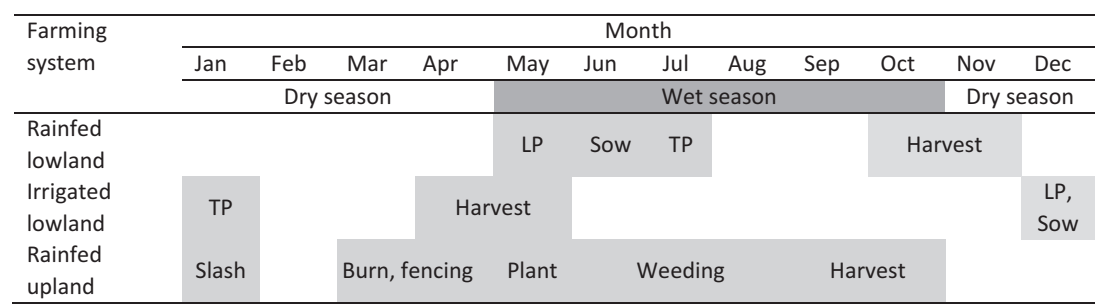

Source: Adapted from Linquist et al. (2006: 32)

Note: LP, land preparation; TP, transplant

November, depending on the maturity of the varieties planted. In areas with access to irrigation, rice fields are also supplemented with irrigation water during a drought period in the wet season. In these irrigated area, farmers may grow rice in the dry season as well. After harvesting the wetseason crop, rice fields are irrigated and land preparation begins. The nursery is sown in December and the seedlings are transplanted by early January. Harvesting is completed in April or May. Traditionally, the cultivation of rainfed upland rice starts with the slash-and-burn method of land preparation between January and April. Planting is done in May, weeding between June and August, and harvesting in September or October.

In the lowland rice environment in the past, land was prepared with the use of buffaloes; however, there is now an increasing trend of using handheld tractors for land preparation. Many farmers have their own hand-held tractors or threshing machines, while those who do not have their own can access the services provided by others for a fee. Many farmers have sold 
their livestock, especially cattle and buffaloes, to buy their own tractors. There has also been a recent rise in direct seeding, whether broadcasting or using drill or drum seeders (Mullen et al. 2019). Threshing is also now done with threshing machines, though manual threshing either by hand or by small machines continues to be practised, especially in remote areas. Small combine harvesters are also now starting to appear in the lowland plains. Mechanisation has thus brought some significant changes into the farming systems in the lowlands but is very limited in the upland rice production system; for example, the threshing of upland rice is still done entirely manually.

\section{Trends in Rice Production and Marketing}

There is evidence that the Austroasiatic farmers who occupied the Khorat Plateau on both sides of the Mekong from around 4000 BCE were already cultivating lowland rainfed rice using domesticated buffalo and irontipped ploughs by around 500 BCE (Schiller et al. 2006; Higham 2014). The presence of canals and reservoirs in the southernmost province of Champasak implies that lowland irrigated rice was practised during the period of Khmer dominance from the fifth to eleventh centuries CE. As Tai peoples moved down the Mekong in the first millennium CE they brought with them both rainfed and irrigated wet rice techniques and progressively occupied the minor and major plains referred to above. The Tai settlements were organised into local polities (muang) that exercised control over the surrounding paddy lands and forest resources, progressively pushing the pre-existing populations into the uplands. ${ }^{2}$ From about the eleventh century, some more powerful muang emerged, functioning as small states that controlled land and labour over a larger area (StuartFox 2006). The four oldest and strongest such muang were centred in what are now the provinces of Luang Prabang, Xieng Khouang, Vientiane, and Champasak. All of these depended on domination over farming populations in rice-growing areas capable of producing substantial surpluses. In the fourteenth century the state of Lan Xang, initially based in Luang Prabang, asserted control over land and people throughout the Northern Highlands and the Khorat Plateau. The decision to move the capital to Vientiane in 1560 was partly based on the larger surplus-producing capacity of the more fertile and extensive Vientiane plain (Schiller et al. 2006). 
Under French colonial rule (1893-1945) there was little effort to increase rice production (Schiller et al. 2006). Almost all rice was produced under rainfed conditions and subject to periodic droughts and (in the lowlands) floods. Production was mostly no more than $350,000 \mathrm{t}$ annually; hence, Laos was a rice-importing country, with only the Champasak area consistently producing a surplus. In the post-war decades, efforts to increase rice production were dwarfed by the escalating conflict in Indochina. However, in the early 1970s some IRRI (International Rice Research Institute) varieties were introduced, trials were conducted, and seed multiplication was initiated at the Salakham Rice Research Station near Vientiane (Schiller et al. 2006). In the decade after 1975, when the main thrust of agricultural policy was the collectivisation program, Vietnamese advisers introduced and evaluated many improved varieties but most were non-glutinous, had poor eating quality, and were not widely adopted (except for CR203 which was useful for noodle and beer production). In 1990 about $95 \%$ of the lowland wet-season crop was still based on traditional low-yielding varieties (Inthapanya et al. 2006). Only a small number of higher-yielding glutinous varieties introduced from Thailand were being planted in the lowlands of the Central and Southern Regions (including the aromatic RD6 that helped revolutionise rice farming in Northeast Thailand, as noted in Chap. 2).

In 1991 a long-term collaborative rice research program with IRRI was initiated, with a major focus on varietal improvement (Inthapanya et al. 2006). The priority was to develop high-yielding glutinous varieties for the rainfed and irrigated lowlands. Breeding also emphasised resistance to specific pests and diseases and selecting varieties suited to the droughtprone environments of Central and Southern Laos. A total of seventeen improved varieties were released from 1993 to 2005. All were glutinous and all but two were photoperiod-insensitive, hence potentially suitable for dry-season as well as wet-season production. While some of the varieties had to be withdrawn, there was a high level of farmer acceptance and adoption due to the new varieties' higher yield potential and responsiveness to fertiliser (Fig. 5.2). Further breeding has focused on developing more resilient varieties for specific environments, including microenvironments within the paddy fields which are more or less susceptible to drought during the wet season (Mullen et al. 2019).

From the mid-1990s there has been a steady growth in the Lao rice sector in terms of area, production, and yield (Fig. 5.3). The increase in rice production made the country notionally self-sufficient in rice in 1999, 


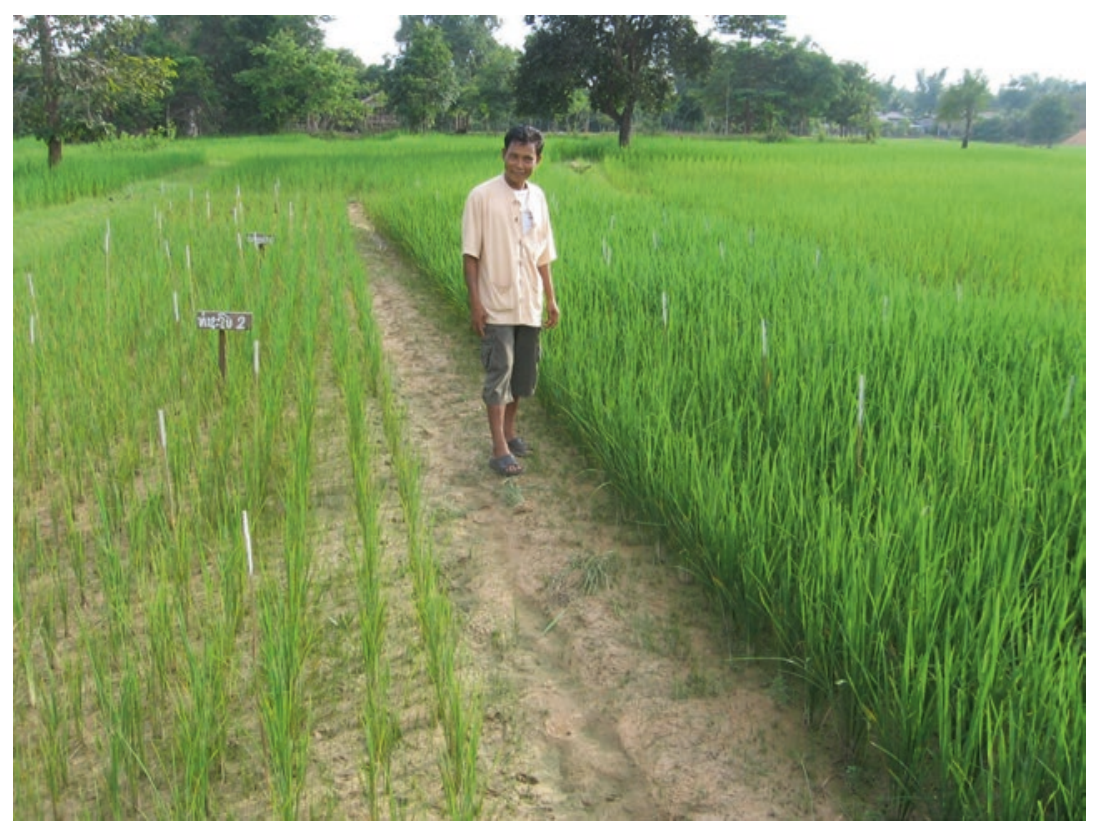

Fig. 5.2 Lao farmer showing field trial on his paddy field. (Source: Rob Cramb)

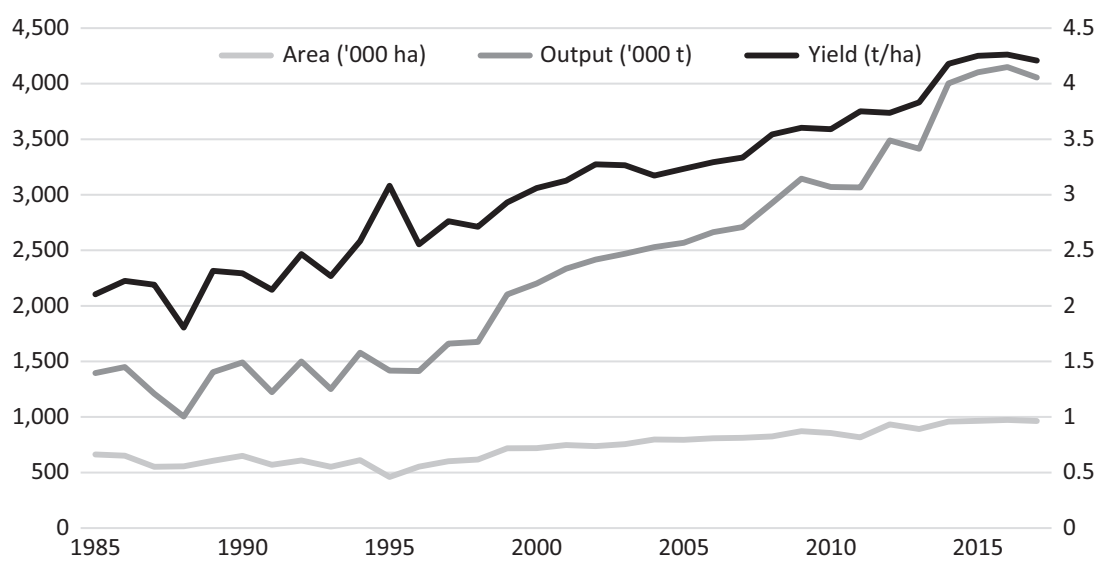

Fig. 5.3 Paddy area, output, and yield in Laos, 1985-2017. (Source: Agricultural Statistics Yearbooks (various years), Department of Planning and Finance, Ministry of Agriculture and Forestry (MAF), Vientiane) 


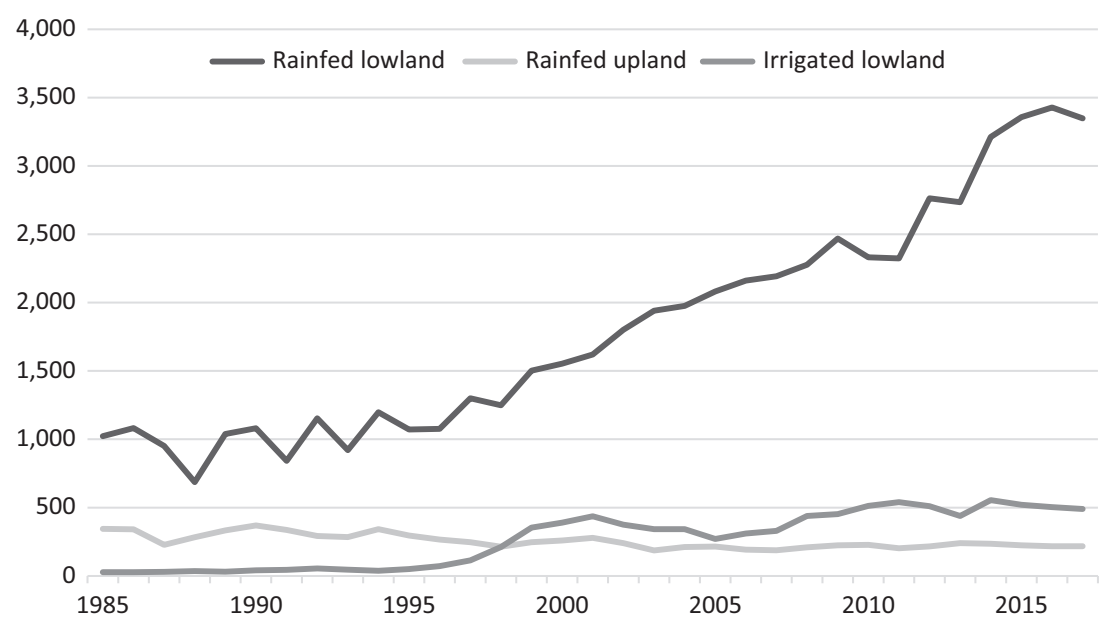

Fig. 5.4 Paddy output in Laos by production system, 1985-2017 ('000 t). (Source: Agricultural Statistics Yearbooks (various years), Department of Planning and Finance, Ministry of Agriculture and Forestry (MAF), Vientiane)

when total paddy production reached 2.1 million tonnes, compared to only 1.4 million tonnes in both 1985 and 1995 . Since then the production has nearly doubled to around 4.1 million tonnes in 2017. The growth in output has been partly due to a doubling in cultivated area from 460,000 ha in 1995 to 964,000 ha in 2017 and partly to a longer-term increase in yields from $2.1 \mathrm{t} / \mathrm{ha}$ in 1985 to $3.1 \mathrm{t} / \mathrm{ha}$ in 1995 and $4.2 \mathrm{t} / \mathrm{ha}$ in 2017 . Though data from field trials and farmer surveys suggest these official figures are somewhat inflated, the overall trend has been confirmed and is attributable to the widespread use of improved rice varieties and management practices, especially the use of fertilisers (Schiller 2008). By the early 2000 s, improved rice varieties covered $70-80 \%$ of lowland ricegrowing areas (Inthapanya et al. 2006).

Most of this growth in production has come from the rainfed lowland environment in the seven large plains, ${ }^{3}$ though there has also been an expansion in irrigated dry-season production (Fig. 5.4). In the 1990s, investment in pump-irrigation schemes in the major plains of Central and Southern Laos increased the dry-season irrigation capacity from only 12,000 ha in 1990 to 102,000 ha in 2001 , leading to a corresponding expansion in dry-season cultivated area to $13-14 \%$ of the total (Schiller et al. 2006). However, there has been little further investment in new 
schemes and the utilisation of existing schemes has declined, mainly due to the poor maintenance of irrigation infrastructure, such that the dryseason cultivated area fell to 97,655 ha in 2017 , representing only $10 \%$ of the total. Nevertheless, dry-season yields are higher than wet-season yields, partly due to the exclusive use of improved varieties, and dry-season production has continued to hover around 500,000 t in the 2010s, contributing 12\% of total paddy output in 2017 (Fig. 5.4). The area and output of upland rice have slowly declined due to a combination of restrictive government policies and diversification into cash crops (Ducourtieux et al. 2005).

Around 2000 it was estimated that only $5 \%$ of total rice production was traded (Bestari et al. 2006). Improved infrastructure, increased urbanisation, and increased regional specialisation in agricultural production (e.g., the growth of rice production in the lowlands of the Central Region and of banana and rubber production for export in the Northern Region) have led to an increase in the share of rice production entering the domestic market (Chap. 8). The marketing system involves various participants, including farmers, assemblers, millers, traders, exporters, retailers, processors, institutional buyers, and consumers. These include private-sector and state-owned enterprises, but the State Food Enterprise, with over 70\% of the market, dominates and controls the rice trade (Setboonsarng et al. 2008 ). Milled rice flows from the provinces with high levels of rice production, such as Champasak, Savannakhet, and Vientiane, to urban centres, in particular Vientiane, and to provinces with low levels of rice production, such as Oudomxay, Luangprabang, and Huaphanh. In addition, provinces sharing borders with Thailand and Vietnam sometimes import rice to fulfil local demand, especially during periods of rice shortage in those provinces (Sengxua et al. 2009). Rice is normally sold in bulk in retail shops in fresh markets or along the streets, but is also available in mini-marts in limited quantity.

Since 2000, rice has also been exported, increasing to a value of USD 37 million or about $130,000 \mathrm{t}$ in 2017 , making it the sixth most valuable agricultural export but representing only $5 \%$ of total rice output (Fig. 5.5). An unrecorded quantity of paddy has also been exported, estimated to be about $248,000 \mathrm{t}$ in 2016 . Exports have mainly been across the borders to Vietnam, Thailand, and China. Rice exported to Thailand is mostly glutinous rice while to Vietnam and China it is largely non-glutinous rice (Bestari et al. 2006; Sengxua et al. 2009). Around 90\% of the rice grown in Laos is glutinous and this limits the export opportunities to interna- 
tional markets, where glutinous rice accounts for less than $2 \%$ of the total traded (GDS 2005). In addition, poor milling and marketing infrastructure constrains the export competitiveness of the rice sector in Laos (Sengxua et al. 2009; Welcher and Prasertsri 2019). Hence the Government is focusing on developing niche markets for rice in which Laos has a comparative advantage, such as organic rice, black rice, or geographic indicator (Lao) rice. A small quantity of organic rice from Laos has been exported to Japan under a contract farming scheme (Setboonsarng et al. 2008). In 2015 the Xuanye (Lao) Company was approved as the sole exporter of rice to China with a quota of $8000 \mathrm{t}$, increasing to $20,000 \mathrm{t}$ in 2017 , including both glutinous and non-glutinous organic rice, drawing on the output of seven mills. However, the company has not been able to fill the quota, supplying only 4000-5000 t per year, largely due to issues with quality. ${ }^{4}$

The current government priorities for rice farming are to ensure food security and improve rural livelihoods by increasing rice productivity to achieve rice self-sufficiency and export the surplus, as well as promoting crop diversification to reduce risks and raise income (MAF 2014). As stated in the Seventh National Socio-Economic Development Plan (20112015 ), the target is to increase rice production to 4 million $t$ with an average yield of $3.9 \mathrm{t} / \mathrm{ha}$. The plan further sets the target to expand the irrigated area to 500,000 hectares by 2015 to increase dry-season production.

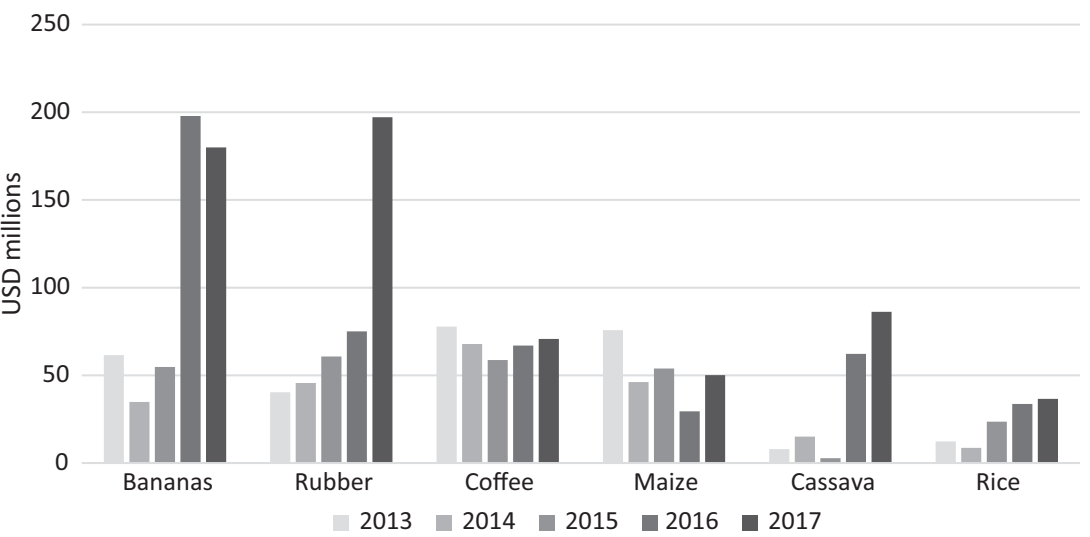

Fig. 5.5 Value of agricultural exports from Laos, 2013-2017. (Source: International Trade Centre) 


\section{ConClusion}

The farming systems in Laos have been undergoing a transition from subsistence-based to market-oriented production. Rice-based farming systems are both diverse and dynamic, with households continually adapting to constraints and opportunities arising from the rapid development occurring within Laos and the wider region. Rice production is dominated by the rainfed lowland system and is still predominantly for subsistence, with only a small proportion marketed and even less exported. However, the cultivated area and especially the yield of both rainfed and irrigated rice have been increasing, contributing to the achievement of rice selfsufficiency at the national level. Moreover, rural livelihoods have become increasingly diversified as the economy of the region develops and opportunities for off-farm and non-farm employment increase.

\section{Notes}

1. The tax on rice output had already been replaced with a land tax in 1979 and official prices of rice and other crops were substantially increased in 1980. These improved incentives led to an increase in rice production of around $17 \%$ in the early 1980 s (Schiller et al. 2006).

2. Fieldwork by Silinthone Sacklokham in Savannakhet Province in Laos uncovered a locally written manuscript (Implantation des Phouthai dans La Ville de la Nam Se Pone) recounting the history of Phouthai settlement in the upriver village of Xepon. The manuscript describes in detail how the Phouthai (a Tai group) had migrated down the Mekong to escape oppression from the Chinese in Yunnan and, having arrived in the Xepon stream, a tributary of the Banghiang River, had forced the pre-existing Mon-Khmer people (referred to as Khas, meaning "subservient peoples") into the surrounding hills.

3. Eliste and Santos (2012) observe that $70 \%$ of the production increase in 1995-2010 came from five provinces-Savannakhet, Vientiane Capital, Vientiane, Khammouane, and Saravan - with over half coming from the Vientiane and Savannakhet Plains.

4. Vientiane Times, 22 March 2017, http://www.vientianetimes.org.la/ FreeContent/FreeConten_Rice.htm.

\section{REFERENCES}

Bestari, N. G., Shrestha, S., and Mongcopa, C. J., 2006. Lao PDR: An Evaluation Synthesis on Rice. A Case Study from the 2005 Sector Assistance Program Evaluation for the Agriculture and Natural Resources Sector in the Lao People's 
Democratic Republic. Vientiane: Operations Evaluation Department, Asian Development Bank.

Cramb, R. A., and Newby, J. C., 2015. Trajectories of rice-farming households in Mainland Southeast Asia. In R. A. Cramb, ed., Trajectories of Rice-Based Farming Systems in Mainland Southeast Asia, pp. 35-72. Canberra: Australian Centre for International Agricultural Research.

Ducourtieux, O., Laffort, J. R., and Sacklokham, S., 2005. Land policy and farming practices in Laos. Development and Change 36: 499-526.

Eliste, P., and Santos, N., 2012. Lao People's Democratic Republic Rice Policy Study 2012. Rome: Food and Agriculture Organization (FAO).

Evans, G., 1988. Agrarian Change In Communist Laos. Singapore: Institute of Southeast Asian Studies.

Evans, G., 1995. Lao Peasants Under Socialism And Post-Socialism. Chiangmai: Silkworm Books.

GDS, 2005. Integrated Value Chain Analysis of Selected Strategic Sectors in Lao People's Democratic Republic. Virginia: Global Development Solutions.

Higham, C., 2014. Early Mainland Southeast Asia: From First Humans to Angkor. Bangkok: River Books.

ICEM, 2003. Lao PDR National Report on Protected Areas and Development. Review of Protected Areas and Development in the Lower Mekong River Region. Brisbane: International Centre For Environment Management (ICEM).

Inthapanya, P., Boualaphanh, C., Hatsadong, and Schiller, J. M., 2006. The history of lowland rice variety improvement in Laos. In J. M. Schiller, M. B. Chanphengxay, B. A. Linquist, and S. Appa Rao, eds., Rice in Laos. Los Banos, Philippines: International Rice Research Institute.

Linquist, B. A., Keoboualapha, B., Sipaseuth, and Inthapanya, P., 2006. Rice production systems of Laos. In J. M. Schiller, M. B. Chanphengxay, B. A. Linquist, and S. Appa Rao, eds., Rice in Laos. Los Banos, Philippines: International Rice Research Institute.

MAF, 2010. Fourth National Report to the Convention on Biological Diversity. Vientiane: Ministry of Agriculture and Forestry (MAF).

MAF, 2014. Strategy for Agricultural Development to 2020. Vientiane: Ministry of Agriculture and Forestry.

Manivong, Vongpaphane, Cramb, Rob, and Newby, Jonathan 2014. Rice and remittances: crop intensification versus labour migration in Southern Laos. Human Ecology 42(3): 367-379.

MINC, 2000. 25 Years of Lao PDR. Vientiane: Ministry of Information and Culture.

MPI and UNDP, 2009. Employment and Livelihoods Lao PDR, 2009. Fourth National Human Development Report. Vientiane: Ministry of Planning and Investment (MPI) and United Nations Development Programme (UNDP).

Mullen, J., Malcolm, B., and Farquarson, B., 2019. Impact Assessment of ACIARsupported Research in Lowland Rice Systems in Lao PDR. ACIAR Impact 
Assessment Series No. 97. Canberra: Australian Centre for International Agricultural Research.

Muto, Chiaki, Ishikawa, Ryuji, Olsen, Kenneth M., Kawano, Kazuaki, Bounphanousay, Chay, Matoh, Toru, and Sato, Yo-Ichiro, 2016. Genetic diversity of the $w x$ flanking region in rice landraces in northern Laos. Breeding Science 66(4): 580-590.

Nguyen, H. T. M., Do, H., Kay, A., Kompas, T., Nguyen, C. N., and Tran, C. T., 2017. The Political Economy of Policy Exceptionalism during Economic Transition: The Case of Rice Policy in Vietnam. Crawford School Working Paper No. 1713. Canberra: Crawford School of Public Policy, Australian National University.

NSC, 2004. The Households of Lao PDR: Social and Economic Indicators. Lao Expenditure and Consumption Survey 2002/03 (LECS 3). Vientiane: National Statistics Centre.

NSC, 2005. Statistics of Lao PDR 1975-2005. Vientiane: National Statistics Centre. Schiller, J. M. 2008. Rice Production: Status and Needs Relating to Future Food Security of Lao PDR and Potential Development Options for Southern Lao PDR. Vientiane: Asian Development Bank.

Schiller, J. M., Linquist, B., Douangsila, K., Inthapanya, P., Douang Boupha, B., Inthavong, S., and Sengxua, P. 2001. Constraints to rice production in Laos. In S. Fukai, and J. Basnayake, eds., Increased Lowland Rice Production In the Mekong Region. ACIAR Proceedings No. 101. Canberra: ACIAR

Schiller, J. M., Hatsadong, and Doungsila, K., 2006. A history of rice in Laos. In J. M. Schiller, M. B. Chanphengxay, B. A. Linquist, and S. Appa Rao, eds., Rice in Laos. Los Banos, Philippines: International Rice Research Institute.

Sengxua, P., Manivong, V., Xayachack, S., and Sayavong, S. 2009. Rapid Assessment of Stocks and Marketing System of Paddy/Rice in Lao PDR. Vientiane: National Agriculture and Forestry Research Institute and Food and Agriculture Organization.

Setboonsarng, S., Leung, P. S., and Stefan, A. 2008. Rice Contract Farming in Lao PDR: Moving from Subsistence to Commercial Agriculture. ADBI Discussion Paper 90. Tokyo: Asian Development Bank Institute.

Stuart-Fox, M. 1996. Buddhist Kingdom, Marxist State: The Making Of Modern Laos. Bangkok: White Lotus.

Stuart-Fox, M. 1997. A History Of Laos. Cambridge: Cambridge University Press. Stuart-Fox, M., 2006. Population diversity and rice in Laos. In J. M. Schiller, M. B. Chanpengxay, B. A. Linquist, and S. Appa Rao, eds., Rice in Laos, pp. 1-8. Los Banos, Philippines: International Rice Research Institute.

UNDP, 2002. National Human Development Report Lao PDR 2001: Advancing RuralDevelopment. Vientiane: United Nations Development Programme(UNDP). Welcher, P., and Prasertsri, P., 2019. Laos Rice Report MY2018-2019. GAIN Report No. TH9016. Bangkok: USDA Foreign Agricultural Service.

World Bank, 2019. The World Bank in Lao PDR. Available at https://www.worldbank.org/en/country/lao (accessed 15 May 2019). 
Open Access This chapter is licensed under the terms of the Creative Commons Attribution 4.0 International License (http://creativecommons.org/licenses/ by $/ 4.0 /$ ), which permits use, sharing, adaptation, distribution and reproduction in any medium or format, as long as you give appropriate credit to the original author(s) and the source, provide a link to the Creative Commons licence and indicate if changes were made.

The images or other third party material in this chapter are included in the chapter's Creative Commons licence, unless indicated otherwise in a credit line to the material. If material is not included in the chapter's Creative Commons licence and your intended use is not permitted by statutory regulation or exceeds the permitted use, you will need to obtain permission directly from the copyright holder.

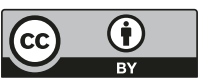

